\title{
The Establishment of Strategy-Training-Based Writing Teaching Mode via Language Experiment Platform (LEP)
}

\author{
JIAO Li-xia \\ Beijing University of Posts and Telecommunications, Beijing, China
}

\begin{abstract}
The present paper establishes the strategy-training-based writing teaching mode via Language Experiment Platform (LEP). The mode aims to improve non-English major students' comprehensive use of metacognitive, cognitive, and social-affective strategies in writing. The three types of strategies, especially cognitive strategies, are further classified into more specific subtypes so that the training can be done gradually and systematically in both classroom settings and out of classes. The fundamental purpose is to help overcome such barriers in college writing teaching as not enough time, too big classes, and too heavy burden for teachers. Hopefully, students can raise their awareness and the actual use of strategy use in writing, their learner autonomy, and eventually their overall writing proficiency.
\end{abstract}

Keywords: strategy training, language experiment platform, strategy use, learner autonomy, writing proficiency

\section{Introduction}

Writing, as an important skill of output in foreign language acquisition, has been a constant headache for students, especially for many non-English major learners. Since October 2013, the researcher has assigned different writing tasks to 14 different classes. Learners have been required to write compositions on topics of different genres, including narration (such as Recent Changes in My Family Life), description (such as the description of a person, place, building, etc.), exposition (such as On Human Nature and How Can Man Tackle Climate Changes), and argumentation (such as Is Our Society Safe and Can Man Conquer Nature). Applied writings are also included, such as the writing of letters of application and thank-you letters. Over the years, 1,977 compositions have been collected, which has provided abundant research materials for the researcher, who detected numerous problems of various types in the writings. The researcher has identified students' nine major problems with word choice (JIAO, 2012). Apart from word choice problems, students also have problems in content, organization, grammar, etc. When it comes to time limited writing, the problems would be more serious.

Lists of possible factors may have contributed to students' incompetency in writing. In many colleges and universities in China, there is no writing course at all. Writing is usually taught as a supplement in intensive reading classes and it only accounts for a minute proportion of the classes. Both teachers and students actually spend little time and energy in writing. Even if teachers spend time in dealing with writing, they seldom systematically elaborate on writing strategies. So when students are practicing writing, they have no idea about how to practice. Therefore, although they have written a lot, both teachers and students themselves cannot feel

JIAO Li-xia, lecturer, master, School of Humanities, Beijing University of Posts and Telecommunications. 
much progress in their writings. Moreover, students do not have sufficient input in English, so they cannot actually improve their writing proficiency despite lots of practice. On account of these, our school has built a platform via which teachers can introduce writing strategies, give well-selected reading materials, assign writing tasks, and give feedback on students' writings. Learners can acquire writing strategies, read authentic materials, fulfill writing tasks, and interact with their teachers or peers about writing strategies and writing tasks. A strategy-training-based teaching mode via the language experiment platform is thus designed.

\section{Related Theories}

\section{Definition and Classification of Learning Strategies}

Scholars (Stern, 1983; Weinstein \& Mayer, 1986; Chamot, 1987; Rubin, 1987; Oxford, 1989) have given different definitions for learning strategies. Language learning strategies are defined in the present paper as "the conscious behaviors or thoughts learners engage in in the process of language acquisition intended to enhance their language competence and performance". Here, strategies refer to both general approaches and specific actions or techniques used to learn an L2. Scholars at home and abroad (O'Malley \& Chamot, 1990; Oxford, 1990; WEN, 1995) have classified strategies into different types based on different criteria. CHENG Xiao-tang and ZHENG Min (2003) pointed out that the divergence in the existing definitions and classifications results from different strategies identified in different studies and different understandings of the language learning process. And two classification schemes are nowadays more frequently adopted: According to the role strategies play in the learning process, we have cognitive, metacognitive, affective, and communicative strategies; with regard to the division between knowledge and skills, we have strategies for learning pronunciation, grammar, vocabulary, and strategies for developing listening, speaking, reading, and writing skills. The present paper focuses on the three main types of strategies, including metacognitive, cognitive, and social-affective strategies in writing. And these strategies can be further divided into subtypes.

\section{Research Into the Use of Learning Strategies in Writing}

Many researchers have done researches into the use of learning strategies in writing. WANG Jun-ju (2007) mentioned the studies conducted by Khaldieh (2000), Zhu (2001), and Olivares-Cuhat (2002) and pointed out that learning strategies in writing and the combination of qualitative and quantitative studies are the new areas of writing research. XU Jin-fen and TANG Fang (2007) conducted the case studies by comparing the metacognitive knowledge of five good learners and five poor learners in English writing and found that the good learners have a better mastery of metacognitive knowledge than the poor ones and the former did better in strategy use and writing processes. CHANG Jun-yue, ZHANG Ying-yi, and CHEN Jing (2009) probed into teachers' teaching strategies in enlarged writing classes and put forward suggestions on how to teach writing in enlarged classes. XU Fang and DING Yan-ren (2010) tracked and described the strategy use of six students from English major to solve lexical problems in time-limited writing by asking the students to think aloud and interviewing and testing them. The profound research is instructive, but it only covers the lexical strategy use in writing. ZHAO Jiang-kui (2011) conducted a study into college students' motivation adaptation strategies in writing and found that motivation adaptation strategies exert significant influence on students' writing proficiency and their use of English learning strategies. But motivation is only one component of metacognitive strategies. PANG Hui (2012) comes up with the suggestions that metacognitive, cognitive, and social-affective strategy training should all be strengthened among non-English major students by conducting questionnaires 
and surveys. LIU Shi-sheng and LIU Mei-hua (2013) examine the processes of English writing by 20 university EFL learners, the challenges they encountered during the process, and the strategies they employed to handle the challenges. Their efforts to pay heed to the writing process instead of just the outcome are appreciated, but the suggestions they offered are too general to be followed. Apart from the studies mentioned above, YANG Shu-xian (2002), LU Wen-jun (2006), XU Heng and GAN Wen-ning (2007), HAN Song (2008), RAN Zhou-lin (2011), QIN Xiao-qing and BI Jing (2012), HUI Liang-hong and MA Shuo (2012), ZHENG Yao-fei (2012), and WU Rong-hui and HE Gao-da (2014) have also conducted various studies into the strategy use in writing. But none of the studies covered all the three major types of strategies. The present study is to implement strategy training for non-English major students in extra-large classes via the Language Experiment Platform (LEP).

\section{Language Experiment Platform (LEP)}

The language experiment platforms were developed by BUPT (Beijing University of Posts and Telecommunications) based on constructivism and task-based language teaching theory. The LEP of Writing was designed by the present researcher and her colleagues. Learners are expected to fulfill different tasks or experiments in the process of language learning. The LEP of Writing is composed of two major centers, as is shown in Figure 1.

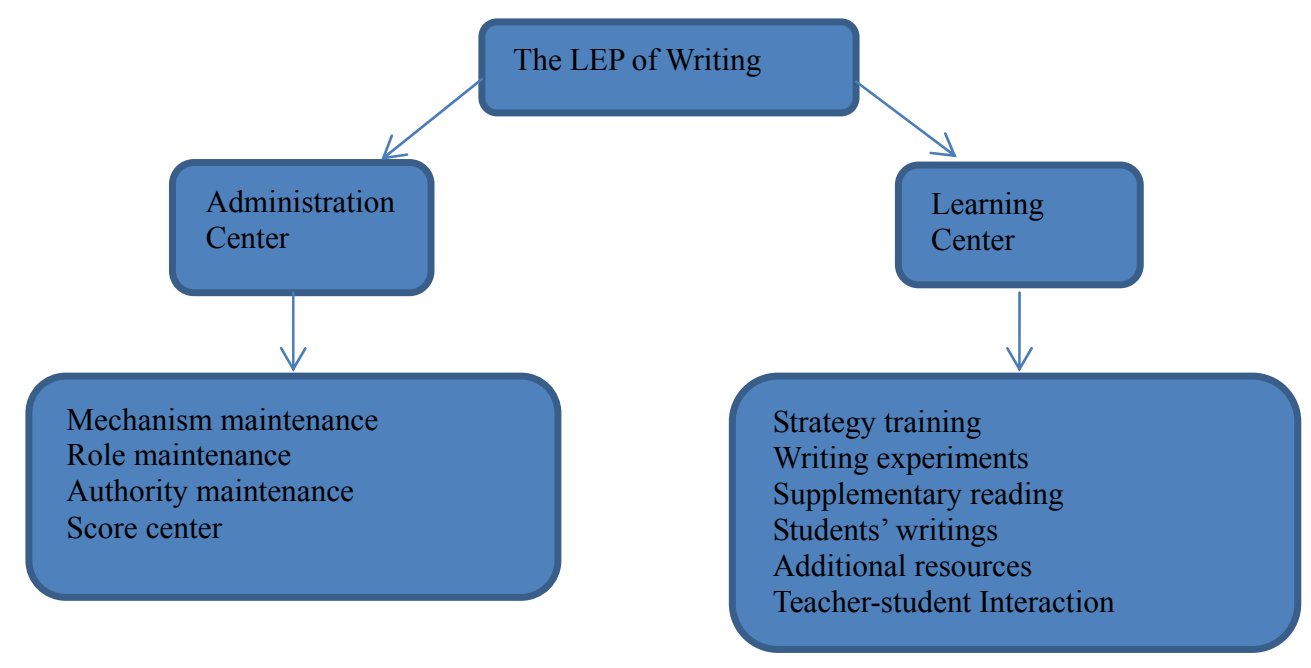

Figure 1. Components of language experiment platform.

The administration center is responsible for the information management of students' universities or colleges, schools or departments, majors and classes, data importing, adjusting, editing, and deleting, defining different roles and rights of system administrators, teachers and students, grouping students in terms of different criteria and the calculating, the importing and exporting of students' scores over terms or semesters. The learning center consists of the following modules: strategy explanation (different categories of writing strategies and their subcategories are listed and illustrated), writing experiments (altogether 12 types of writing experiments are included: assessment, differentiation, error correction, blank filling, paragraph extending, translation, writing outlines, passage rewriting, imitation writing, writing specific paragraphs, writing the whole passages, and commenting on videos. Some of them are to be done individually, some in pairs and still others in groups. After the students have finished the experiments, they are supposed to self-assess and peer assess 
their tasks and then teachers are to assess the students' tasks), supplementary reading (some well-selected reading materials are provided to aid students' writing), students writing (this module further contains two subcategories: excellent writings and problematic writings. Students are to appreciate the well-written passages and detect the problems in problematic writings), additional resources (related audios, videos, and websites are provided), teacher-student interaction (notices, blogs, discussion board, and wiki will facilitate the communication between teachers and students and among students themselves).

\section{The Strategy-Training-Based Writing Teaching Mode via LEP}

Writing strategies covered here include metacognitive, cognitive, and social-affective strategies. The categorization of each type is shown as follows:

Table 1

General Categories of Writing Strategies

\begin{tabular}{|c|c|c|c|}
\hline \multirow{21}{*}{$\begin{array}{l}\text { Writing } \\
\text { strategies }\end{array}$} & \multirow{4}{*}{$\begin{array}{l}\text { Metacognitive } \\
\text { strategies }\end{array}$} & \multicolumn{2}{|c|}{ Making both long-term and short-term plans } \\
\hline & & \multicolumn{2}{|c|}{ Monitoring the acquisition of writing proficiency as a whole and each writing process } \\
\hline & & \multicolumn{2}{|c|}{ Assessing the writing process and outcome } \\
\hline & & \multicolumn{2}{|c|}{ Reflecting on the writing process and outcome individually and with peers } \\
\hline & \multirow{12}{*}{ Cognitive strategies } & \multirow{6}{*}{ General strategies } & Reading \\
\hline & & & Recitation \\
\hline & & & Imitation \\
\hline & & & Attaching equal importance to form and content \\
\hline & & & Revising \\
\hline & & & Rewriting \\
\hline & & \multirow{6}{*}{ Specific strategies } & For content \\
\hline & & & For organization \\
\hline & & & For grammar \\
\hline & & & For sentences \\
\hline & & & For diction \\
\hline & & & For rhetoric \\
\hline & \multirow{5}{*}{$\begin{array}{l}\text { Social-affective } \\
\text { strategies }\end{array}$} & \multicolumn{2}{|c|}{ Improving the attitude towards writing } \\
\hline & & \multicolumn{2}{|c|}{ Maintaining the proper anxiety level } \\
\hline & & \multicolumn{2}{|c|}{ Stimulating both intrinsic and extrinsic motivation } \\
\hline & & \multicolumn{2}{|c|}{ Enhancing self-confidence in writing } \\
\hline & & \multicolumn{2}{|c|}{ Strengthening cooperation with peers } \\
\hline
\end{tabular}

As is seen in Table 1, cognitive strategies can further be divided into general and specific strategies. The general ones include reading English originals and sample writings, reciting carefully-selected passages, consciously imitating sample writings, attaching equal importance to form and content, carefully revising one's own compositions, rewriting one's own compositions for improvement. When it comes to the various aspects in writing, including the content, the organization, the grammar, the sentences, and the diction, more specific strategies can be used. 
Table 2

Special Categories of Cognitive Strategies

\begin{tabular}{|c|c|c|}
\hline \multirow{21}{*}{$\begin{array}{l}\text { Cognitive } \\
\text { strategies } \\
\text { (specific) }\end{array}$} & \multirow{5}{*}{ Content } & Brainstorming \\
\hline & & Developing dialectical thinking \\
\hline & & Developing creative and critical thinking \\
\hline & & Ensuring the unity and logicality of content \\
\hline & & Guaranteeing the conciseness of the content \\
\hline & \multirow{4}{*}{ Structure } & Writing an outline \\
\hline & & Arranging the content in terms of importance \\
\hline & & Dividing paragraphs properly \\
\hline & & Using transitional devices properly \\
\hline & \multirow{4}{*}{ Sentences } & Using sentences of different functions (statements, questions, exclamations, imperatives) \\
\hline & & $\begin{array}{l}\text { Using sentences of different structures (simple sentences, coordinate sentences, } \\
\text { compound sentences, and coordinate compound sentences) }\end{array}$ \\
\hline & & Using special sentential structures, such as emphatic sentences, double negation, etc.) \\
\hline & & $\begin{array}{l}\text { Using clauses of different patterns, including SV, SVO, SVC, SVA, SVOO, SVOC, and } \\
\text { SVOA }\end{array}$ \\
\hline & \multirow{5}{*}{ Diction } & Increasing vocabulary in context through reading, listening, writing etc. \\
\hline & & Using Chinese-English and English-English dictionaries together \\
\hline & & $\begin{array}{l}\text { Choosing the proper and appropriate words in terms of their meaning, including choosing } \\
\text { the subordinate instead of the superordinate, distinguishing synonyms, and homoionym of } \\
\text { different emphasis and different degrees), formality (deciding whether the words should } \\
\text { be used in formal, informal, literary or colloquial styles), and colors (deciding whether the } \\
\text { words are commendatory or derogatory). }\end{array}$ \\
\hline & & Correcting spelling errors and improving the diversity of word use \\
\hline & & Using chunks \\
\hline & \multirow[b]{2}{*}{ Grammar } & Familiarizing oneself with English grammar \\
\hline & & $\begin{array}{l}\text { Overcoming grammatical errors in writing, such as the errors made in such aspects as the } \\
\text { case, number and gender of nouns, the tenses and voices of verbs, the agreement between } \\
\text { subjects and objects, etc. }\end{array}$ \\
\hline & Rhetoric & $\begin{array}{l}\text { Consciously using some rhetoric devices if necessary, such as simile, metaphor, } \\
\text { metonymy, hyperbole, personification, etc. }\end{array}$ \\
\hline
\end{tabular}

Strategy training can be carried out both in class and out of class. In class, strategy training should follow the procedure: teachers explaining the specific strategy, teachers modeling the strategy use, students practicing the strategy use, teachers assigning the writing task (requiring students to use the strategy). After class, strategy training can be done online. Students log on to the LEP and go over the different modules. In the "strategy training" module, students familiarize themselves with the strategy the teacher has explained in class by reading more samples given. In the "writing experiments" module, students finish the assigned writing task by making use of the strategy that has just been explained in class. Students are also able to assess their writings individually and with peers. After students have finished the self-assessment and peer assessment, teachers can assess students' writings and give proper feedback. In the "supplementary reading" module, students are provided with some teacher-carefully-selected passages. Teachers' guidelines about how to read each passage are given so that students are target-oriented in reading. They are to direct their attention to the use of a certain strategy in the passage. The "students' writings" module contains two parts: excellent writings by students and problematic writings by students. Teacher's assessment of the writings is given. In the "additional resources" module, relevant audios, videos, or the websites are offered. The "teacher-student interaction" module further contains various tools with one of which all the students can interact with each other or they can interact with 
the teacher or they can have further discussion in small groups about the strategy use in writing or any other questions related to writings.

\section{Conclusion}

The strategy-training-based writing teaching mode aims to familiarize students with different strategies so as to improve their overall writing proficiency. The different modules will enable students to fully understand the different strategies through much reading, sampling, and interaction with the teacher and peers so that they can acquire the strategy use both in classroom settings and out of classes, which will aid students' Self-access Language Learning (SALL) as "there is some evidence that learners find SALL useful (and sometimes enjoyable)" (Gardner \& Miller, 2007, p. 25) and hopefully the strategy use will help students to improve their writings. And extra exposure to language is also beneficial for students. Of course, to what degree the mode will help students to improve their writing proficiency is to be found with empirical studies conducted among students.

\section{References}

CHANG, J. Y., ZHANG, Y. Y, \& CHEN, J. (2009). An empirical study of problems and coping strategies in the teaching of English writing in enlarged classes. Foreign Languages and Their Teaching, 12, 23-26.

CHENG, X. T., \& ZHENG, M. (2003). English learning strategies. Beijing: Foreign Language Teaching and Research Press.

CHMOT, A. U. (1987). The learning strategies of ESL students. Englewood Cliffs, NJ: Prentice Hall.

Gardner, D., \& Miller, L. (2007). Establishing self-access from theory to practice. Shanghai: Shanghai Foreign Language Education Press.

JIAO, L. X. (2012). Improve diction in writing through reading. Sino-US English Teaching, 8, 1414-1420.

LIU, S. S., \& LIU, M. H. (2013). The process, challenges and strategies of college students' writing: Case study. Foreign Language Education, 4, 46-49.

O’Malley, J. M., \& Chamot, A. U. (1990). Learning strategies in second language acquisition. Cambridge: Cambridge University Press.

Oxford, R. (1990). Language learning strategies: What every teacher should know. New York: Newbury House/Harper Collins.

Oxford, R. L. (1989). Use of language learning strategies: A synthesis of studies with implications for teaching training. System 17, 235-247.

PANG, H. (2012). The investigation of non-English major students' writing strategy use. Education Exploration, 3, 64-65.

Rubin, J. (1975). What the "good language learner" can teach us. TESOL Quarterly, 9, 41-45.

Stern, H. (1983). Fundamental concepts of language teaching. Oxford: Oxford University Press.

WANG, J. J. (2007). Review of the cognitive psychological processes of second language writing. Foreign Language World, 5 , $2-7$.

Weinstein, C., \& Mayer, R. (1986). The teaching of learning strategies. New York: Macmillan.

WEN, Q. F. (1995). On English learning strategies. Shanghai: Shanghai Foreign Language Education Press.

XU, F., \& DING, Y. R. (2010). Research into English major students' strategy use to solve lexical problems in time-limited writing. Chinese Foreign Language, 2, 54-62.

XU, J. F. (2007). Research into the differences in metacognitive knowledge between good language learners and poor language learners. Journal of PLA University of Foreign Languages, 6, 44-48.

ZHAO, J. K. (2011). The documentation of learners' English writing motivation adaptation strategies and the impacts of the strategies. Education Researches and Experiments, 6, 78-82. 